Discussion Paper No. 04-45

\title{
B2B or Not to Be: Does B2B E-Commerce Increase Labour Productivity?
}

Irene Bertschek, Helmut Fryges and Ulrich Kaiser

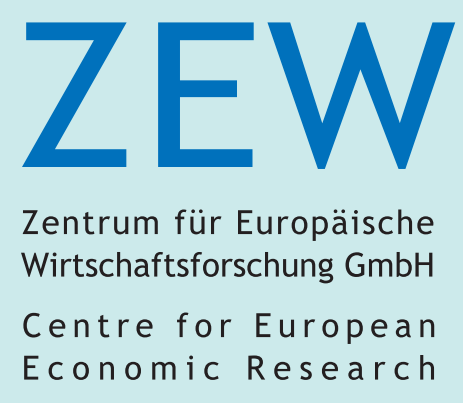


Discussion Paper No. 04-45

\title{
B2B or Not to Be: Does B2B E-Commerce Increase Labour Productivity?
}

\author{
Irene Bertschek, Helmut Fryges and Ulrich Kaiser
}

Download this ZEW Discussion Paper from our ftp server:

\author{
ftp://ftp.zew.de/pub/zew-docs/dp/dp0445.pdf
}

Die Discussion Papers dienen einer möglichst schnellen Verbreitung von neueren Forschungsarbeiten des ZEW. Die Beiträge liegen in alleiniger Verantwortung der Autoren und stellen nicht notwendigerweise die Meinung des ZEW dar.

Discussion Papers are intended to make results of ZEW research promptly available to other economists in order to encourage discussion and suggestions for revisions. The authors are solely responsible for the contents which do not necessarily represent the opinion of the ZEW. 


\section{Non-technical summary}

The productivity-enhancing impact of information and communication technologies (ICT) has come to be indisputable. Especially at the micro-level there is broad empirical evidence for positive impacts of ICT on labour productivity. These studies, however, mostly consider ICT-investment or ICT-capital as an aggregate variable not taking into account the heterogeneity that might be hidden behind ICT. Not much is known yet about the productivity effects of specific ICT-components or applications.

Policy makers and businesses, backed by numerous economists, have pinned high hopes on electronic commerce as one of the most promising Internet applications. $\mathrm{E}$-commerce is said to reduce transaction costs by making geographic and time restrictions obsolete. In this paper, we estimate the effects of e-commerce on labour productivity, thus trying to validate the claim of productivity-enhancing effects of ecommerce. To date, the B2B- (business-to-business) e-commerce segment accounts for more than $80 \%$ of total e-commerce sales worldwide with an increasing tendency. Therefore, our analysis is restricted to $\mathrm{B} 2 \mathrm{~B}$ e-commerce only.

Our model takes into account potential simultaneity between labour productivity and B2B. Not only may B2B affect labour productivity, but firms may decide to use $\mathrm{B} 2 \mathrm{~B}$ in order to increase their labour productivity or, put differently, the more productive firms might have a higher probability of engaging in a new IT application like B2B. Moreover, the model allows firms to follow different structural production regimes depending on whether or not they use B2B.

The model is applied to a sample of 1,394 German firms in the manufacturing and selected services sectors. The estimation results reveal that (i) it is appropriate to consider labour productivity and B2B as simultaneous factors, (ii) the output elasticity of ICT-investment is significantly larger for firms using B2B than for firms not using it, (iii) the multifactor productivity is significantly larger in the regime with B2B. These results indicate that due to strategic complementarities firms with $\mathrm{B} 2 \mathrm{~B}$ produce more efficiently and use their ICT-investment more efficiently than firms without B2B. Finally, (iv) labour productivity is increased by using B2B. Firms that do not use B2B would profit from using B2B with respect to labour productivity although not to the same extent as firms that already use B2B. 


\title{
B2B or Not to Be: Does B2B E-Commerce Increase Labour Productivity?
}

\author{
Irene BertscheK* ${ }^{*}$ Helmut Fryges ${ }^{\dagger}$, Ulrich Kaiser ${ }^{\ddagger}$
}

July 2004

\begin{abstract}
We implement an endogeneous switching-regression model for labour productivity and firms' decision to use business-to-business (B2B) e-commerce. Our approach allows B2B usage to affect any parameter of the labour productivity equation and to properly take account of strategic complementarities between the input factors and B2B usage. Empirical evidence from 1,394 German firms shows that firms using B2B e-commerce have a significantly higher output elasticity with respect to ICT-investment and produce significantly more efficiently than firms that do not use B2B. Firms' labour productivity is enhanced by using B2B.
\end{abstract}

\section{JEL-classification: C21, D24}

Keywords: Business-to-business e-commerce, labour productivity, endogenous switching regression model, survey data

\footnotetext{
${ }^{1}$ We thank Ramona Hönicke, Friedhelm Sauer and Jan Sauermann for competent research assistance and Philip Savage for proofreading the paper.

${ }^{*}$ Corresponding author: ZEW (Centre for European Economic Research), Research Group Information and Communication Technologies, P.O. Box 103443, D-68034 Mannheim, Germany, email: bertschek@zew.de.

${ }^{\dagger}$ ZEW (Centre for European Economic Research), Department of Industrial Economics and International Management, P.O. Box 103443, D-68034 Mannheim, Germany, email: fryges@zew.de.

${ }^{\ddagger}$ University of Southern Denmark at Odense, Dept. of Economics, Campusvej 55, 5230 Odense M, Denmark; email: uka@sam.sdu.dk, Internet: www.sam.sdu.dk/staff/uka, ZEW (Centre for European Economic Research), Mannheim, and Centre for Economic and Business Research, Copenhagen.
} 


\section{Introduction}

The fast technological development of the Internet as well as its declining prices have led to an increased diffusion of the Internet during the last few years. In 2002, the Internet penetration rate for businesses was more than 90 percent in the U.S. as well as in many European countries. The Internet penetration rate in German businesses increased from 87 percent in 2000 to 97 percent in 2002 (NFO Infratest, 2003, p.133).

One important application of Internet technology for firms is so-called Internet commerce or electronic commerce. Policy makers and businesses, backed by numerous economists, have pinned high hopes on e-commerce which is said to reduce transaction costs, increase market transparency and make the course of business more efficient. In this paper, we estimate the effects of e-commerce on labour productivity, thus trying to validate the claim of productivity-enhancing effects of e-commerce.

E-commerce has been hailed as one of the most promising media for ordering, buying and selling products and services which has the potential to considerably reduce transaction costs. E-commerce between companies (business-to-business e-commerce or B2B e-commerce) has a broader scope than e-commerce between companies and consumers (business-to-consumers or B2C). As shown for example in NFO Infratest (2003, p.234), in 2002, the B2B segment accounted for more than $80 \%$ of total e-commerce sales worldwide with an increasing tendency. In Germany, according to a representative survey of the ZEW (Centre for European Economic Research), the B2B segment accounts for about $85 \%$ of total e-commerce sales in the manufacturing industry and for about $60 \%$ in the services industry in 2002 . Therefore, our analysis is restricted to B2B e-commerce only. Meanwhile, it has become common knowledge that ICT-capital positively affects labour productivity, see for example Bertschek (2003) and Brynjolfsson and Hitt (2000) for recent surveys referring to firm-level evidence. However, studies focussing on certain kinds of ICT applications are still scarce.

The approach chosen in this work addresses the simultaneity between adopting ecommerce and labour productivity: e-commerce might affect labour productivity but the causality could also run the other way round since e-commerce might be adopted precisely in order to increase productivity. Moreover, firms might produce according to different production function regimes depending on whether or not they use B2B e-commerce. This flexibility takes account of the likely presence of complementarities between the use of $\mathrm{B} 2 \mathrm{~B}$ e-commerce and production input factors. Milgrom and Roberts (1990) demonstrate that firms need to implement computer technology as part of a system or cluster of organizational change. This argument of strategic complementarity has been further advanced in studies by Brynjolfsson and Mendelson (1993) as well as by Radner (1993). It might thus be too restrictive 
to assume that firms produce according to the same production function independent of the type of ICT application they use. It seems rather likely that firms that use $\mathrm{B} 2 \mathrm{~B}$ e-commerce do not only differ from other firms with respect to the use of this ICT application, but also in various other respects such as skill mix or investment strategies. Thus, firms with B2B might have larger production elasticities with respect to their input factors than firms not using B2B.

Our empirical results are based on a sample of 1,394 firms from the German manufacturing and selected services sectors. They emphasize the importance of considering B2B e-commerce and labour productivity as simultaneous factors. In other words: there is a two-way relationship between the adoption of $\mathrm{B} 2 \mathrm{~B}$ e-commerce and labour productivity, with both mutually affecting one another. We also find that the output elasticity with respect to ICT-investment as well as the multifactor productivity turn out to be significantly larger in the production function regime using $\mathrm{B} 2 \mathrm{~B}$ e-commerce than in the regime not using $\mathrm{B} 2 \mathrm{~B}$. The estimation of productivity differentials shows that firms that use B2B are better off in terms of their labour productivity compared to the case where they did not use B2B. Conversely, firms that do not use $\mathrm{B} 2 \mathrm{~B}$ would be better off if they engaged in $\mathrm{B} 2 \mathrm{~B}$, but to a lesser extent than those firms that already use B2B.

We also find that drivers of $\mathrm{B} 2 \mathrm{~B}$ e-commerce usage produce with a knowledgeintensive production process, and that international business activities are positively related to firms' probability of using B2B.

The paper is organized as follows: section 2 contains the theoretical considerations and the empirical model, section 3 describes the data, section 4 presents the empirical results and section 5 concludes.

\section{Model}

According to Lucking-Reiley and Spulber (2001, p. 56), B2B e-commerce might have positive impacts on the productivity of an enterprise via four channels: efficiencies from automation of transactions, economic advantages of new market intermediaries, the consolidation of demand and supply through organized exchange, and changes in the extent of vertical integration of companies. The aspect of transaction costs is also studied by Garicano and Kaplan (2000). Thus, by applying B2B e-commerce, a firm might reap productivity gains compared to a firm that does not make use of $\mathrm{B} 2 \mathrm{~B}$ e-commerce. It seems, however, likely that firms that use B2B e-commerce do not only differ from other firms with respect to their use of specific new technologies and the related organizational form but also in various other respects such as skill mix or investment strategies. Milgrom and Roberts (1990) demonstrate that firms need 
to implement computer technology as part of a system or cluster of organizational changes. This argument of strategic complementarity has been further advanced in studies by Brynjolfsson and Mendelson (1993) as well as by Radner (1993).

Our study adopts the framework of Bertschek and Kaiser (2004). This approach takes into account the likely presence of complementarities between the use of B2B e-commerce and the production input factors and allows the labour productivity parameters to be different depending on whether or not firms use B2B e-commerce.

In our model, we assume that firm $i$ produces according to a Cobb-Douglas production technology. Output $y_{i}$ is a function of ICT-capital, $I C T_{i}$, non-ICT-capital, $K_{i}$, and labour input, $L_{i}$ :

$$
y_{i}=A_{i} I C T_{i}^{\alpha} K_{i}^{\beta} L_{i}^{\gamma}
$$

The vector $A_{i}$ captures differences in production efficiency not related to the input factors. It comprises a constant term reflecting multifactor productivity as well as further variables taking account of industry-specific and regional differences. The exponents $\alpha, \beta$ and $\gamma$ denote the elasticities of output with respect to ICT-capital, non-ICT- capital and labour, respectively. Taking logs and adding an i.i.d. error term denoted by $\epsilon_{i}$ leads to

$$
\ln \left(y_{i}\right)=\ln \left(A_{i}\right)+\alpha \ln \left(I C T_{i}\right)+\beta \ln \left(K_{i}\right)+\gamma \ln \left(L_{i}\right)+\epsilon_{i} .
$$

Labour productivity, i.e. output per worker, is then given by:

$$
\ln \left(\frac{y_{i}}{L_{i}}\right)=\ln \left(A_{i}\right)+\alpha \ln \left(I C T_{i}\right)+\beta \ln \left(K_{i}\right)+(\gamma-1) \ln \left(L_{i}\right)+\epsilon_{i}
$$

If a firm uses B2B e-commerce, its labour productivity is

$$
\begin{aligned}
\ln \left(\frac{y_{i}}{L_{i}}\right)_{B 2 B}= & \ln \left(A_{i B 2 B}\right)+\alpha_{B 2 B} \ln \left(I C T_{i}\right)+\beta_{B 2 B} \ln \left(K_{i}\right)+ \\
& +\left(\gamma_{B 2 B}-1\right) \ln \left(L_{i}\right)+\epsilon_{i B 2 B} \\
= & \boldsymbol{X}_{\boldsymbol{i}} \boldsymbol{\delta}_{\boldsymbol{B 2} \boldsymbol{B}}+\epsilon_{i B 2 B} .
\end{aligned}
$$


For firms not using the Internet for B2B e-commerce, labour productivity is

$$
\begin{aligned}
\ln \left(\frac{y_{i}}{L_{i}}\right)_{n B 2 B}= & \ln \left(A_{i n B 2 B}\right)+\alpha_{n B 2 B} \ln \left(I C T_{i}\right)+\beta_{n B 2 B} \ln \left(K_{i}\right)+ \\
& +\left(\gamma_{n B 2 B}-1\right) \ln \left(L_{i}\right)+\epsilon_{i n B 2 B} \\
= & \boldsymbol{X}_{\boldsymbol{i}} \boldsymbol{\delta}_{\boldsymbol{n} \mathbf{2} \mathbf{B}}+\epsilon_{\text {inB2B }}
\end{aligned}
$$

where the subscripts $B 2 B$ and $n B 2 B$ denote the two productivity regimes with and without $\mathrm{B} 2 \mathrm{~B}$ e-commerce activities, respectively.

Firms decide to use e-commerce if the productivity gain from B2B is larger than the costs per worker involved with the adoption of $\mathrm{B} 2 \mathrm{~B}, C_{i}$. Thus, the latent variable

$$
I_{i}^{*}=a\left(\ln \left(\frac{y_{i}}{L_{i}}\right)_{B 2 B}-\ln \left(\frac{y_{i}}{L_{i}}\right)_{n B 2 B}\right)-C_{i}+u_{i}
$$

represents the difference between the productivity gains and the costs arising from $\mathrm{B} 2 \mathrm{~B}$ e-commerce, where $a$ represents the effect of the productivity gains from B2B e-commerce on the decision about whether or not to use $\mathrm{B} 2 \mathrm{~B}$, and $u_{i}$ is an i.i.d. distributed error term. Substituting equations (4) and (5) into equation (6), the selection mechanism for observing an adoption of B2B e-commerce then is

$$
B 2 B_{i}= \begin{cases}1 & \text { if } I_{i}^{*}>0 \\ 0 & \text { otherwise }\end{cases}
$$

where

$$
I_{i}^{*}=a \boldsymbol{X}_{\boldsymbol{i}}\left(\boldsymbol{\delta}_{B 2 B}-\boldsymbol{\delta}_{n B 2 B}\right)-C_{i}+u_{i}=Z_{i} \Pi+v_{i}>0 .
$$

The selection equation is estimated as a reduced form. The parameter vector $\boldsymbol{Z}_{\boldsymbol{i}}$ includes both the variables $\boldsymbol{X}_{\boldsymbol{i}}$ that explain labour productivity and the variables that influence the costs $C_{i}$ of $\mathrm{B} 2 \mathrm{~B}$ adoption and that identify the selection equation. The error term $v_{i}=a \cdot\left(\epsilon_{i B 2 B}-\epsilon_{i n B 2 B}\right)+u_{i}$ follows a normal distribution. If $a=0$, the decision to use $\mathrm{B} 2 \mathrm{~B}$ is unaffected by the productivity differences. If, further, the correlation coefficients between the error terms of the productivity equations $\epsilon_{i B 2 B}$ and $\epsilon_{i n B 2 B}$, respectively, and the error term of the selection equation $v_{i}$ are both equal to zero, i.e. if $\rho_{B 2 B}=0$ and $\rho_{n B 2 B}=0$, the model reduces to an exogenous switching regression model (Maddala, 1983, pp. 283-284). In this case, 
the productivity equations could be estimated by OLS and the selection equation could be estimated by a probit model.

The endogenous switching regression model is estimated by Full Information Maximum Likelihood. ${ }^{1}$

In a further step, a firm's productivity in the case of using B2B may be compared to the hypothetical productivity that this firm would achieve if it did not use B2B, and vice versa, the productivity of a firm without $\mathrm{B} 2 \mathrm{~B}$ is compared to the hypothetical case that this firm did use B2B. Hence, in order to control for the firms' selection decision, the productivity is calculated conditional on the firm's choice whether or not to use B2B. Otherwise, the estimation results might be biased (see for instance Greene, 2000, pp. 926-934, for further details). The estimated productivity differential for firms that use B2B can then be calculated as follows:

$$
\begin{aligned}
P D_{i B 2 B}= & E\left[\ln \left(y_{i} / L_{i}\right)_{B 2 B} \mid X_{i}, B 2 B=1\right] \\
& -E\left[\ln \left(y_{i} / L_{i}\right)_{n B 2 B} \mid X_{i}, B 2 B=1\right] \\
= & X_{i}\left(\delta_{B 2 B}-\delta_{n B 2 B}\right)+\left(\theta_{B 2 B}-\theta_{n B 2 B}\right) \lambda_{i B 2 B}
\end{aligned}
$$

where the first term of equation (9) represents the expected labour productivity for firms with $\mathrm{B} 2 \mathrm{~B}$ e-commerce, the second term is the expected labour productivity for firms with $\mathrm{B} 2 \mathrm{~B}$ in the hypothetical case that they had not chosen to use B2B. $\lambda_{i B 2 B}=\phi\left(\boldsymbol{Z}_{\boldsymbol{i}} \boldsymbol{\Pi}\right) / \Phi\left(\boldsymbol{Z}_{\boldsymbol{i}} \boldsymbol{\Pi}\right)$ and $\theta_{B 2 B}=\rho_{B 2 B} \sigma_{B 2 B}, \theta_{n B 2 B}=\rho_{n B 2 B} \sigma_{n B 2 B}$ where $\phi(\cdot)$ and $\Phi(\cdot)$ represent the density and the distribution function of the standard normal distribution. The term $X_{i B 2 B}\left(\delta_{B 2 B}-\delta_{n B 2 B}\right)$ represents the unconditional expected value of the log-labour productivity differential, depending on the observable variables, i.e. due to a varying endowment with production factors. The second term $\left(\theta_{B 2 B}-\theta_{n B 2 B}\right) \lambda_{i B 2 B}$ represents the impact of the firms' selection on using B2B e-commerce where $\lambda_{i B 2 B}$ is the inverse of Mill's ratio. For the opposite case, $\lambda_{i n B 2 B}=-\phi\left(\boldsymbol{Z}_{\boldsymbol{i}} \boldsymbol{\Pi}\right) /\left(1-\Phi\left(\boldsymbol{Z}_{\boldsymbol{i}} \boldsymbol{\Pi}\right)\right)$.

\section{Data and Descriptive Analysis}

The data result from a CATI-survey (computer-aided telephone interview) based on a stratified random sample of about 11,000 German firms. The sample was stratified by sector ${ }^{2}$, size class and region, i.e. West and East Germany. Only firms with at least five employees were included in the survey, $50 \%$ thereof in the manufacturing

\footnotetext{
${ }^{1}$ For further details see Bertschek and Kaiser (2004). The GAUSS code for the Maximumlikelihood function can be downloaded at http://www.ulrichkaiser.com/papers/orga.html.

${ }^{2}$ The sectors that were included in the study are listed in detail in the Appendix.
} 
industry and $50 \%$ in the service sector. The source data set originates from Creditreform, the largest German credit rating agency. ${ }^{3}$ The survey was conducted in the year 2000 .

About 4,400 firms participated in the survey, which corresponds to a response rate of approximately 43\%. After performing consistency checks and due to item nonresponse concerning the variables that were included in the empirical model (see below), a sample of 1,394 firms forms the basis for the empirical analysis. The relatively high loss of observations is primarily due to item non-response with respect to ICT-investment by which we will approximate ICT-capital in the empirical model. Obviously, it is very difficult for firms to state the value of investment in ICT by phone. This seems to be especially true for large firms (200 and more employees). Therefore, large firms are underrepresented in our sample used for the empirical analysis compared to the random sample as well as with the complete sample of responding firms. Moreover, firms from the service sectors "other business services", retail and wholesale trade, and financial intermediaries as well as firms from the chemical industry are underrepresented, whereas firms from the sectors "other basic goods industries" and "mechanical engineering" are overrepresented. With the exception of financial intermediaries, this selection bias corresponds to the sectoral distribution of firms in the complete responding sample of all 4,400 firms and is insofar not a result of item non-response. Fortunately, no systematic difference in the use of $\mathrm{B} 2 \mathrm{~B}$ e-commerce is found if the reduced sample is compared to the whole sample of all firms that participated in the survey.

To operationalize the firms' involvement in electronic commerce, firms have been asked whether they use the Internet for distributing products and/or services to other companies and, in a further question, whether they use the Internet for ordering products and/or services from other companies. According to the OECD (1999, p. 28) the definitions of e-commerce vary between "including all financial and commercial transactions that take place electronically, including electronic data interchange (EDI), electronic funds transfers (EFT), and all credit/debit card activity", and limiting e-commerce "to retail sales to consumers for which the transaction and payment take place on open networks like the Internet". The definition of ecommerce in this study is a rather narrow one, including only the ordering and selling of products and services on the Internet. Only those firms selling their products/services via the Internet to other firms are considered as firms actively using B2B. As previously mentioned, B2B e-commerce is still the most widespread application of e-commerce. Moreover, selling products/services reflects an active way of implementing (B2B) e-commerce. Firms have to build up an electronic trade

\footnotetext{
${ }^{3}$ As Germany's largest credit rating agency, Creditreform has the most comprehensive database of German firms at its disposal. Creditreform provides data on German firms to the Centre for European Economic Research (ZEW) for research purposes.
} 
platform on their server, they have to reorganize their logistics and workplaces in order to guarantee a smooth handling of orders they receive via the Internet and in order to fully explore probable efficiency gains of their e-commerce activities. ${ }^{4}$ In contrast, using the Internet only passively in the sense of buying products and/or services does not necessarily require substantial adjustments of business activities, although these firms might reduce their search and transaction costs and possibly profit from a larger market transparency.

One major drawback of our data is that we do not know how much of a firm's products/services are sold through $\mathrm{B} 2 \mathrm{~B}$ e-commerce. The questionnaire simply asked whether the firm conducts $\mathrm{B} 2 \mathrm{~B}$ e-commerce in general. Just under the half of the firms of our sample use B2B e-commerce for selling their products/services. Table 1 shows the shares of firms making use of B2B e-commerce by industry based on the sample that is used for the estimations in section 4 .

Table 1: B2B e-commerce for selling products/services by industry sectors

\begin{tabular}{l|cc}
\hline \hline & \multicolumn{2}{|c}{ B2B e-commerce in \% } \\
Industry & no use & use \\
\hline Consumer goods industry & 60.0 & 40.0 \\
Chemical industry & 42.3 & 57.8 \\
Other basic goods industry & 50.0 & 50.0 \\
Mechanical engineering & 48.6 & 51.5 \\
Electrical engineering & 42.9 & 57.1 \\
Medical, precision and optical instruments & 50.0 & 50.0 \\
Motor manufacturing industry & 53.8 & 46.2 \\
Wholesale trade & 50.6 & 49.4 \\
Retail trade & 58.6 & 41.4 \\
Transport and postal services & 54.0 & 46.0 \\
Financial intermediation & 51.5 & 48.5 \\
Computer and telecommunication services & 29.1 & 70.9 \\
Technical business services & 52.8 & 47.2 \\
Other business services & 61.0 & 39.0 \\
\hline ICT-sector & 34.4 & 65.6 \\
\hline All sectors & 50.3 & 49.7 \\
\hline \hline
\end{tabular}

Source: ZEW survey.

\footnotetext{
${ }^{4}$ The relation between the introduction of new ICTs and the need for organizational changes in the firm in order to achieve positive productivity effects is examined for instance by Bresnahan, Brynjolfsson and Hitt (2002) and is also discussed by Brynjolfsson and Hitt (2000).
} 
As expected, the most intensive use of B2B e-commerce can be observed within the computer and telecommunication services sector, followed by the chemical industry and electrical engineering. The computer and telecommunication services and electrical engineering also form the majority of the ICT-sector as defined by the OECD (2000). Moreover, the manufacturing of precision instruments and industrial process control equipment as well as specialized ICT-traders belong to the ICT-sector. ${ }^{5}$ The adoption rate of $\mathrm{B} 2 \mathrm{~B}$ e-commerce is rather low in the consumer goods industry, in the retail trade sector (including ICT traders) and among non-technical business services.

In order to estimate production functions for the two productivity regimes with and without B2B e-commerce, we have to measure labour productivity, ICT-capital and non-ICT-capital. Labour productivity is calculated as the ratio of total sales to the total number of employees. Since no information about the two capital variables is available in our survey data, non-ICT-capital is measured as investment in physical capital and ICT-capital is proxied by ICT-investment. Proxying ICT-capital by ICT-investment does not appear as a severe shortcoming since ICT depreciates extremely quickly (Dewan and Min, 1997). With regard to the empirical proxy for non-ICT-capital, it is important to note that a capital stock could theoretically be calculated using the perpetual inventory method. However, our analysis is based on a cross-sectional data set so that we can only observe investment in physical capital for one period.

Table 2: Descriptive statistics

\begin{tabular}{lrrrrr}
\hline \hline & & Quantile & & \\
& $10 \%$ & $50 \%$ & $90 \%$ & Mean & Std. Dev. \\
\hline ICT-investment $^{\dagger}$ & 7 & 50 & 900 & 994.9 & $6,454.3$ \\
Non-ICT-investment $^{\dagger}$ & 100 & 800 & 15,000 & $46,371.8$ & $1,340,115.0$ \\
\# of employees $_{\text {Output }^{\dagger}}^{\star}$ & 8 & 50 & 650 & 565.7 & $7,180.6$ \\
Labour productivity $^{\ddagger}$ & 1,800 & 13,000 & 210,000 & $331,076.8$ & $4,640,717.0$ \\
\hline firm age (in years) & 103 & 233 & 700 & 495.2 & $1,305.6$ \\
export share & 4 & 13 & 73 & 26.5 & 30.4 \\
\hline \hline
\end{tabular}

$\dagger$ in 1,000 DM.

* Balance-sheet total for banks, sum insured for insurance companies.

$¥$ Output (total sales in 1999) per employee in 1,000 DM (Output measured as balancesheet total for banks, sum insured for insurance companies).

Source: ZEW survey, own calculations.

\footnotetext{
${ }^{5} \mathrm{~A}$ detailed description of the ICT-sector is given in the Appendix.
} 
The upper part of Table 2 displays the quantiles, means and standard deviations of the variables used in the estimation of labour productivity: ICT-investment, nonICT-investment (both in 1,000 DM), output (proxied by total sales in 1,000 DM), the number of employees and productivity (output per employee). All quantitative numbers refer to the year 1999.

The standard deviations of non-ICT-investment, the number of employees and the output are quite large. Moreover, the distributions of all five variables in the upper part of Table 2 are highly skewed. Apart from labour productivity and the number of employees, the mean is even higher than the $90 \%$ percentile. This observation is due to the fact that small retailers as well as the largest German manufacturing companies are both included in our sample.

Both means and medians of non-ICT-investment are larger than those related to ICT investment. In all sectors non-ICT-investment dominates ICT-investment. The relative importance of ICT-investment, however, differs significantly across sectors. In computer and telecommunication services ICT-investment accounts for one third of companies' total gross investment. In contrast to this, the share of ICT-investment of gross investment in the basic goods industry or for transport and postal services is less than $10 \%$.

Table 3 shows descriptive statistics of labour productivity (total sales per employee) separated for firms that carry out B2B e-commerce and firms without B2B ecommerce, respectively. The mean of labour productivity is slightly higher for firms that sell their products/services via the Internet compared with firms that don't have any B2B e-commerce activities. However, based on a t-test the difference is not significant at any conventional level, which might be expected considering the relatively high standard deviations. When calculating the logarithm of labour productivity and comparing the means in the two productivity regimes, however, a t-test shows that the mean of the logarithm of labour productivity is significantly higher in the regime of firms with B2B e-commerce activities.

Since direct cost effects from using a new technology like B2B generally cannot be identified in a straightforward way, one might draw up several hypotheses concerning the factors that are likely to influence the benefits and costs of B2B and which, in turn, might affect a firm's decision to use B2B e-commerce. In order to consistently estimate the coefficients of the productivity equations, exclusion restrictions have to be found which explain the use of B2B e-commerce but do not necessarily affect productivity. The selection equation therefore contains the following variables as exclusion restrictions: export share, firm age, number of software applications and foreign location.

Using a new technology might depend on the presence of international involvement. It seems plausible that companies engaged in export activities are more likely to 
Table 3: Comparison of mean labour productivity with and without B2B

\begin{tabular}{|c|c|c|c|c|c|c|}
\hline & & & Quantil & & & \\
\hline & $\mathrm{N}$ & $10 \%$ & $50 \%$ & $90 \%$ & Mean & Std. Dev. \\
\hline Firms with B2B & & & & & & \\
\hline Labour Productivity $^{\dagger}$ & 693 & 106 & 250 & 800 & 499.3 & $1,198.4$ \\
\hline Firms without B2B & & & & & & \\
\hline Labour Productivity ${ }^{\dagger}$ & 701 & 100 & 217 & 647 & 491.1 & $1,404.3$ \\
\hline$t$-test on the equalit & of $t$ & he $\mathrm{me}$ & ans 0 & labo & ur prod & tivity \\
\hline $\mathrm{H}_{0}: \operatorname{mean}(\mathrm{w} / \mathrm{I}$ & $2 \mathrm{~B})$ & mean & $\mathrm{w} / \mathrm{O} \mathrm{B}$ & $2 B)=$ & $\operatorname{diff}=0$ & $t=-0.1165$ \\
\hline $\mathrm{H}_{1}:$ diff $<0 \rightarrow$ & {$[P<$} & $t]=0$. & 4536 & & & \\
\hline $\mathrm{H}_{1}: \operatorname{diff}=0 \rightarrow$ & {$[P>$} & $|t|]=($ & .9072 & & & \\
\hline$t$-test on the equalit & of $t$ & he $\mathrm{me}$ & ans 0 & $\ln ($ la & bour $p$ & ductivity) \\
\hline $\mathrm{H}_{0}: \operatorname{mean}(\mathrm{w} / \mathrm{I}$ & 2B) & mean & $\mathrm{w} / \mathrm{o} \mathrm{B}$ & $2 \mathrm{~B})=$ & $\operatorname{diff}=0$ & $t=-2.0970$ \\
\hline $\mathrm{H}_{1}:$ diff $<0 \rightarrow$ & {$[P<$} & $t]=0$. & 0181 & & & \\
\hline $\mathrm{H}_{1}:$ diff $=0 \rightarrow$ & {$[P>$} & $|t|]=($ & .0362 & & & \\
\hline
\end{tabular}

† Output (total sales in 1999) per employee in 1,000 DM (Output measured as balancesheet total for banks, sum insured for insurance companies).

Source: ZEW survey, own calculations.

use B2B e-commerce, since in this case the benefits of B2B e-commerce in terms of transaction cost reduction can be expected to be even higher than the reduction of transaction costs of only domestic sales. This argument holds especially in the context of digital products when transaction costs are considerably reduced since the products can be sent via Internet to almost any place on Earth. Moreover, recent evidence from the manufacturing industry on the relationship between productivity and export activity reveals that causality runs from productivity to exports rather than vice versa. Thus, more productive firms are more likely to export their goods than less productive firms (see for example Arnold and Hussinger, 2004). This evidence supports our choice of export activity as an instrument for explaining the use of B2B e-commerce. A firm's export activity is captured by the share of sales obtained by exports (export quota). Moreover, a dummy variable indicating whether the firm has a location or subsidiary in a foreign country is included in the selection equation.

According to Christensen and Rosenbloom (1995), new firms are more flexible and thus more likely to adopt a new technology than old firms. In the empirical implementation of our model the age of a firm is represented by two dummy variables. The first dummy takes the value one, if the firm is three years old and younger, the second dummy indicates, if the age is between four and seven years old. Firms 
older than seven years are the base category. This categorization is plausible since empirical studies for Germany by Prantl (2001) show that hazard functions of young firms reach a first local maximum approximately three years after formation and a second local maximum after approximately seven years. Having survived for seven years, the hazard rates stay at a comparably low level such that these firms can be regarded as established or "old" firms.

Furthermore, the selection equation of the empirical model will include different levels of software applications. In the interviews, firms were asked whether they make use of six different software applications (office software, data bases,software for planning and controlling, software for computer aided design/manufacturing/engineering, electronic data interchange and e-mail). We hypothesize that firms which use a larger number of different software applications are more inclined toward ICT technologies and a knowledge intensive production process. Therefore, we add two dummy variables that control for different levels of software application: the first dummy captures firms that utilize 3 or 4 different software applications, the second dummy refers to firms with at least 5 different software applications. Firms that make use of at most 2 different software applications are used as the base category.

\section{Empirical results}

\subsection{Productivity estimations}

Table 4 displays estimation results for the labour productivity equations with and without $\mathrm{B} 2 \mathrm{~B}$ e-commerce. In addition, it presents the results of tests for identical coefficients in the two different regimes, e.g. we test whether the coefficients of $\ln (I C T), \ln (K)$ and $\ln (L)$ are the same in the regime with $\mathrm{B} 2 \mathrm{~B}$ as in the regime without B2B.

Positive and highly significant effects of non-ICT-investment and labour on labour productivity are found in both productivity estimations, as shown in Table $4 .{ }^{6} \mathrm{Al}-$ though the point estimates of these partial production elasticities are generally larger in the regime with $\mathrm{B} 2 \mathrm{~B}$ e-commerce than in the regime without $\mathrm{B} 2 \mathrm{~B}$, identity of these parameters cannot be rejected at the usual significance levels. B2B ecommerce hence has a fairly sizeable but insignificant effect on the partial output elasticities of non-ICT-investment and labour input.

However, the partial elasticity of ICT-investment is significantly larger for firms that use $\mathrm{B} 2 \mathrm{~B}$ e-commerce than for those who do not use B2B. In the latter case,

\footnotetext{
${ }^{6}$ Note that for labour input, the estimated coefficients displayed in Table 4 correspond to $\gamma-1$, so that adding 1 to the estimated coefficients yields the partial output elasticity of labour.
} 
the estimate of the coefficient of ICT-investment is even not significantly different from zero at the usual significance levels. Consequently, Wald tests for the identity of the coefficients of the three input factors as well as testing for the identity of the coefficients of the entire set of variables included in the level equations reject identity. Thus, firms that use B2B e-commerce seem to exploit their ICT-investment more efficiently than those not adopting B2B. ICT-investment and B2B can be interpreted as complementary factors positively affecting firms' labour productivity.

Another important result is that the constant terms representing the multifactor productivity (corresponding to the constant term of parameter $A_{i}$ in equation (1)) differ significantly between the two regimes, being larger in the regime with $\mathrm{B} 2 \mathrm{~B}$ than in the regime without $\mathrm{B} 2 \mathrm{~B}$. This implies that companies that use B2B produce more efficiently than other firms.

In the regime with $\mathrm{B} 2 \mathrm{~B}$, the partial elasticity of output with respect to ICTinvestment does not differ significantly from the partial elasticity with respect to non-ICT-investment ( $p$-value equals 0.8174). Further, the sum of the three input elasticities amounts to 1.0411, and the Null hypothesis of constant returns of scale $(\alpha+\beta+\gamma=1)$ cannot be rejected at any usual significance level (Wald $\chi^{2}=3.5213$; $p$-value $=0.3180)$. On the other hand, in the regime without B2B e-commerce the hypothesis of constant returns to scale cannot be confirmed due to the relatively small partial elasticity of non-ICT-investment (Wald $\chi^{2}=14.1063 ; p$-value $=0.0028$ ).

In both regimes, the dummy variable for East Germany has a negatively significant coefficient, reflecting the lower labour productivity especially in the East German manufacturing sector. Identity of these coefficients between the two regimes cannot be rejected.

Most of the sector dummies included in the level equations are highly significant. However, in our estimations the coefficients of the sector dummies have no economic interpretation. Rather, they control for different measurements of labour productivity across sectors. The labour productivity of financial intermediaries is calculated as the balance-sheet total per employee for banks, or the sum insured per employee for insurance companies. Therefore, the sector of financial intermediation shows a significantly higher labour productivity. The industries of the base category (trade, transport and postal services) are all at the end of the value-added chain, reaching a high value of total sales per employee. Compared to these industries, all other industries that produce at earlier stages of the value-added chain have a significantly lower value of total sales per employee.

In our estimation, the parameters $\rho_{B 2 B}$ and $\rho_{n B 2 B}$ measuring the correlation between the error term of the labour productivity equation of firms with (without) B2B and the error term of the selection equation are individually and jointly significant, indicating that treating $\mathrm{B} 2 \mathrm{~B}-$ usage as truly exogenous for labour productivity is 
Table 4: Switching regression estimation results: level equations

\begin{tabular}{|c|c|c|}
\hline & Coeff. & Std. err. \\
\hline \multicolumn{3}{|c|}{ Estimation results for regime $\mathrm{w} / \mathrm{B} 2 \mathrm{~B}$} \\
\hline $\ln (I C T)$ & $0.1306^{* * *}$ & 0.0259 \\
\hline $\ln (K)$ & $0.1221^{* * *}$ & 0.0222 \\
\hline $\ln (L)$ & $-0.2116^{* * *}$ & 0.0343 \\
\hline dummy manuf. without ICT ${ }^{\dagger}$ & $-0.3993^{* * *}$ & 0.0860 \\
\hline dummy financial intermediation & $0.7419^{* * *}$ & 0.1771 \\
\hline dummy technical services & $-0.7714^{* * *}$ & 0.1367 \\
\hline dummy other business services & $-0.4216^{* * *}$ & 0.1611 \\
\hline dummy ICT sector & $-0.6680^{* * *}$ & 0.1140 \\
\hline East Germany & $-0.3642^{* * *}$ & 0.0732 \\
\hline Constant & $5.7724^{* * *}$ & 0.2347 \\
\hline$\rho_{B 2 B}$ & $-0.3878^{*}$ & 0.2136 \\
\hline$\sigma_{B 2 B}$ & $0.8172^{* * *}$ & 0.0501 \\
\hline \multicolumn{3}{|c|}{ Estimation results for regime $\mathrm{w} / \mathrm{o} \mathrm{B} 2 \mathrm{~B}$} \\
\hline $\ln (I C T)$ & 0.0391 & 0.0280 \\
\hline $\ln (K)$ & $0.1116^{* * *}$ & 0.0261 \\
\hline $\ln (L)$ & $-0.2465^{* * *}$ & 0.0410 \\
\hline dummy manuf. without ICT ${ }^{\dagger}$ & -0.1497 & 0.0971 \\
\hline dummy financial intermediation & $0.7995^{* * *}$ & 0.1908 \\
\hline dummy technical services & $-0.4546^{* * *}$ & 0.1548 \\
\hline dummy other business services & -0.2375 & 0.1620 \\
\hline dummy ICT sector & $-0.5824^{* * *}$ & 0.1372 \\
\hline East Germany & $-0.2959^{* * *}$ & 0.0844 \\
\hline Constant & $5.1104^{* * *}$ & 0.1398 \\
\hline$\rho_{n B 2 B}$ & $-0.8907^{* * *}$ & 0.0218 \\
\hline$\sigma_{n B 2 B}$ & $1.1073^{* * *}$ & 0.0452 \\
\hline
\end{tabular}

\begin{tabular}{lrr}
$\sigma_{n B 2 B}$ & $1.1073^{* * *}$ & 0.0452 \\
\hline \multicolumn{1}{c}{ Wald tests for identity of the coefficients } \\
& $\chi^{2}$ & $p$-value \\
\hline $\ln (I C T)$ & 6.3268 & 0.0119 \\
$\ln (K)$ & 0.1077 & 0.7428 \\
$\ln (L)$ & 0.4894 & 0.4842 \\
Set of input factors & 20.4146 & 0.0001 \\
East Germany & 0.4286 & 0.5127 \\
Sector dummies & 5.7614 & 0.3301 \\
Constant & 6.3521 & 0.0117 \\
Entire specification & 114.0537 & 0.0000 \\
\hline Number of observations $(N)$ & \multicolumn{2}{c}{1,394} \\
\hline \multicolumn{3}{l}{}
\end{tabular}

$\dagger$ A distributive service firm (trade, transport and postal services) that is older than seven years and that utilizes at most two different software applications is used as base category.

* $\quad$ significant on the $10 \%$-level

** significant on the $5 \%$-level

*** significant on the $1 \%$-level

Source: ZEW, own estimation. 
inappropriate. The negative signs of the correlation coefficients indicate that an unanticipated productivity shock leads to a decrease in the firms' propensity to adopt B2B e-commerce.

In order to compare the situation of a firm with $\mathrm{B} 2 \mathrm{~B}$ to the hypothetical situation in which this firm would not have adopted B2B, hypothetical productivity differentials are estimated according to equation (10). The results are depicted in Table 5. The idea behind these estimations is to consider the same firms - those with B2Badoption and those without B2B - under the two different regimes.

Table 5: Test for significant differences in log-labour productivity

\begin{tabular}{lccc}
\hline \hline & $\begin{array}{c}\text { Mean } \\
\text { difference }\end{array}$ & $\begin{array}{c}\text { stand. } \\
\text { error }\end{array}$ & $\begin{array}{c}p \text { - } \\
\text { value }\end{array}$ \\
\hline Firms with B2B & 1.6240 & 0.2346 & 0.0000 \\
Firms without B2B & 0.5279 & 0.2069 & 0.0054 \\
\hline
\end{tabular}

$\bar{\dagger}$ Changes in the log-labour productivity due to B2B e-commerce: Firms with (without) B2B and parameter vector with (without) B2B compared to the situation if they had not (had) adopted $\mathrm{B} 2 \mathrm{~B}$, i.e. parameter vector without (with) B2B plus the respective selectivity terms.

The mean log-labour productivity of firms that use B2B e-commerce turns out to be significantly higher compared to the hypothetical mean log-labour productivity for the case that these firms did not utilize B2B. Similarly, the mean labour productivity of firms without B2B is lower than the hypothetical labour productivity for the case that these firms had adopted B2B e-commerce. Furthermore, the mean difference is larger for firms that currently use B2B than for those not using it: Firms that have already adopted B2B e-commerce have for instance reorganized their logistics and workplaces so that an abandonment of B2B e-commerce transactions would cause a tremendous drop in the firms' productivity. On the other hand, firms that did not use B2B so far would be better off if they adopted B2B, but they would only realize a comparably small gain in productivity, for example because they don't have complementary resources at their disposal in order to fully exploit the productivity potentials of B2B. ${ }^{7}$

\footnotetext{
${ }^{7}$ The results further show, that the unconditional mean difference between the estimated and the hypothetical labour productivity is nearly the same for firms with and without B2B e-commerce respectively. The higher hypothetical gain in productivity for firms with B2B e-commerce is a result of the selection into the regime with B2B. Calculating the productivity differences, it is important to note that the results should only be interpreted qualitatively rather than quantitatively, because we had to approximate ICT-capital and non-ICT-capital by the value of the respective investments. This shortcoming especially affects the estimated difference with respect to the pa-
} 


\subsection{Selection equation}

A result that is important for the empirical validity of the model is that the identifying restrictions (firm age, export quota, software applications) are jointly highly significant in the B2B e-commerce adoption equation (see Table 6). A non-significance would indicate an invalidity of our exclusion restrictions and hence an invalidity of the entire model. Thus, the chosen identifiers seem to proxy quite well the costs involved with B2B.

We find no evidence for an effect of firm age. The categorical variables for the firms' age, distinguishing between three different stages of the firms' life cycle, are insignificant. Thus, there is no support for the hypothesis that younger firms are more likely to use the new technology B2B e-commerce due to their higher flexibility, unconventionality or a higher readiness to take risks.

Analysing the effect of firms' export share, a firm with cross-border business activities is more likely to engage in $\mathrm{B} 2 \mathrm{~B}$ since it can profit more from the reduction of transaction costs compared to a firm that only has domestic sales. It should be noted in this context that our sample includes many firms especially from the service sector that do not export at all. While about $75 \%$ of all firms in our sample that belong to the manufacturing sector said that they exported in 1999, almost $80 \%$ of all service firms reported no exports. Only $5 \%$ of all financial intermediaries and slightly more than $10 \%$ of business service firms exported in the year $1999 .^{8}$ A further variable reflecting international involvement is the dummy 'foreign location'. Its coefficient turns out to be positive and significant, thus supporting the hypothesis that internationally operating firms are more likely to engage in B2B than nationally focussed firms.

As hypothesized, the two dummy variables that capture different levels of software application representing a firm's openness to new ICT applications, increase the probability of using the Internet for B2B e-commerce. This result is supported by the positive and significant effect of ICT-investment in the selection equation. ICT-investment is the only input factor that significantly affects firms' decision to adopt B2B e-commerce. Thus, we conclude that firms with a knowledge-intensive production process are more likely to use B2B e-commerce.

rameter of production efficiency between the two regimes, since the latter reflects inter alia the difference in capital stocks that is not covered by investments.

${ }^{8}$ These figures are based on the firms' own information. Using the definitions of the System of National Accounts, the reported export shares of many firms would be different. For example, every sale of a retailer to a foreigner, a tourist, for example, accounts for export of a retail trade service according to the official definitions. Transactions like this are, however, not very likely to be considered by firms when responding to the question whether they export or not. 
Table 6: Switching regression estimation results: selection equation

\begin{tabular}{lcr}
\hline \hline & Coeff. & Std. err. \\
\hline firm age (3 years and younger) & -0.0620 & 0.1010 \\
firm age $(4 \leq$ years $\leq 7)$ & -0.0316 & 0.0715 \\
export share & $0.0039^{* * *}$ & 0.0013 \\
foreign location/subsidiary & $0.1708^{* *}$ & 0.0821 \\
\# software application 3 or 4 & $0.2624^{* *}$ & 0.1143 \\
\# software application $\geq 5$ & $0.5866^{* * *}$ & 0.1191 \\
$\ln (I C T)$ & $0.0629^{* *}$ & 0.0262 \\
$\ln (K)$ & -0.0109 & 0.0245 \\
$\ln (L)$ & -0.0210 & 0.0381 \\
dummy manuf. without ICT ${ }^{\dagger}$ & -0.0583 & 0.0950 \\
dummy financial intermediation & $-0.3485^{*}$ & 0.1856 \\
dummy technical services & -0.0502 & 0.1477 \\
dummy other business services & -0.2044 & 0.1579 \\
dummy ICT sector & $0.2989^{* *}$ & 0.1247 \\
East Germany & 0.0615 & 0.0791 \\
Constant & $-0.5943^{* * *}$ & 0.1653 \\
\hline
\end{tabular}

\begin{tabular}{lcc}
\hline \multicolumn{3}{c}{ Wald tests for joint significance } \\
& $\chi^{2}$ & $p$-value \\
\hline Entire set of identifiers & 59.9177 & 0.0000 \\
Factor inputs & 6.2506 & 0.1000 \\
Sector dummies & 4.5070 & 0.3417 \\
Entire productivity eq. & 25.7761 & 0.0022 \\
Entire selection eq. & 127.0774 & 0.0000 \\
\hline \multicolumn{4}{c}{ Wald tests for joint significance: } \\
\multicolumn{3}{c}{ entire switching regression model } \\
\hline Correlation coefficients & $1,713.3277$ & 0.0000 \\
Entire switching regression & 508.9646 & 0.0000 \\
\hline Number of observations $(N)$ & 1,394 \\
\hline \hline
\end{tabular}

$\dagger$ A distributive service firm (trade, transport and postal services) that is older than seven years and that utilizes at most two different software applications is used as base category.

* significant on the $10 \%$-level

** significant on the $5 \%$-level

*** significant on the $1 \%$-level

Source: ZEW, own estimation. 
East German firms do not have a significantly different probability to use B2B than their West German competitors. This is plausible, because the costs of adopting B2B e-commerce can be expected to be the same for both East German and West German firms. Finally, there are only minor differences between sectors with respect to the use of B2B. The dummy variable representing the ICT sector is positively significant, which is plausible regarding the descriptive results. A bit surprisingly, financial intermediaries have a lower probability of adopting B2B e-commerce than the base category, a distributive service firm, although the coefficient is significant only on the $10 \%$ level. Obviously, differences between sectors can be traced back to a varying endowment with resources relevant for the use of B2B.

The entire set of variables determining labour productivity is jointly significant in the selection equation, indicating that labour productivity differences are relevant for the decision whether or not to adopt B2B e-commerce. ${ }^{9}$ Thus, we have a complementary relationship between productivity and the use of $\mathrm{B} 2 \mathrm{~B}$.

\section{Conclusions}

This paper studies the effects of $\mathrm{B} 2 \mathrm{~B}$ e-commerce on labour productivity. An endogenous switching regression model takes account of a simultaneous relationship between B2B and labour productivity and allows firms to produce according to structurally different production functions depending on whether or not they engage in B2B. This econometric model is applied to a sample of 1,394 German firms from the manufacturing industry and from selected services sectors.

The results indicate the importance considering $\mathrm{B} 2 \mathrm{~B}$ and labour productivity as simultaneous factors. The output elasticity with respect to ICT-investment turns out to be significantly larger for firms using B2B. Thus, firms with B2B use ICT more efficiently. Moreover, the multifactor productivity is significantly larger for firms with B2B. These results hint at strategic complementarities between B2B and the input factors of the firms leading to labour-productivity enhancing impacts of B2B.

The estimation of hypothetical productivity differentials reveals that firms with B2B are significantly better off if they engage in B2B than if they did not. The same is true for those firms without B2B: they would increase their labour productivity if they adopted B2B. However, the potential productivity gains turn out to be smaller than for those firms already using B2B.

\footnotetext{
${ }^{9}$ Note that the selection equation is estimated in the reduced form so that the parameter $a$ in equation (8) is not estimated directly. However, because the variables of the productivity equations are jointly (and individually) significant, it can be concluded that the adoption of B2B is influenced by productivity differences.
} 
We also find that drivers of B2B e-commerce usage produce with a knowledgeintensive production process, and that international business activities are positively related to firms' probability to use B2B.

Our paper has the following main caveats that are primarily related to data restrictions: (i) We only observe whether or not a firm uses B2B and do not know to what extent B2B is used. (ii) We do not directly observe the costs involved with implementing and using B2B and therefore use proxy variables. (iii) Due to the crosssectional character of our data we use ICT-investment and non-ICT-investment as proxies for ICT-capital and non-ICT-capital. (iv) For the same reason we cannot take into account unobserved heterogeneity which might affect our estimation results.

Further research should attempt to use panel data, if available in the future, in order to overcome these data restrictions in particular with respect to the problem of approximating ICT-capital and non-ICT-capital by investment variables and in order to take account of firm-specific unobserved heterogeneity. 


\section{Appendix}

Table 7: Sectors considered in the sample

\begin{tabular}{l|c}
\hline \hline Industry & NACE-Code \\
\hline Consumer goods industry & $15-22,36,37$ \\
Chemical industry & 23,24 \\
Other basis goods industry & $25,26,27$ \\
Mechanical engineering & 28,29 \\
Electrical engineering & $30-32$ \\
Medical, precision and optical instruments & 33 \\
Motor manufacturing industry & 34,35 \\
Wholesale trade & 51 \\
Retail trade & 50,52 \\
Transport and postal services & $60-63,64.1$ \\
Financial intermediation & $65-67$ \\
Computer and telecommunication services & $64.2,72$ \\
Technical services & $73,74.2,74.3$ \\
Other business services & $70,71,74.1,74.4-74.8,90$ \\
\hline \hline
\end{tabular}

Source: own classification. 
Table 8: Definition of the ICT-sector according to the OECD

\begin{tabular}{l|c}
\hline \hline Industry & NACE-Code \\
\hline Manuf. of office machinery and computers & 30.0 \\
Manuf. of insulated wire and cable & 31.3 \\
Manuf. of electronic values, tubes and & 32.1 \\
other electronic components & 32.2 \\
$\begin{array}{l}\text { Manuf. of telev. and radio transmitters and apparatus } \\
\text { for line telephony and line telegraphy }\end{array}$ & 32.3 \\
Manuf. of television and radio receivers, sound or video & \\
recording or reproducing apparatus and associated goods & 33.2 \\
$\begin{array}{l}\text { Manuf. of instruments and appliances for measuring, } \\
\text { checking, testing, navigating and other purposes }\end{array}$ & 33.3 \\
Manuf. of industrial process control equipment & 51.43 .3 \\
Wholesale of radio and TV goods & 51.64 .1 \\
Wholesale of office machinery & 52.45 .2 \\
Retail sale of radio and TV goods ${ }^{\dagger}$ & 52.48 .4 \\
Retail sale of optical and photographic & \\
goods, computers and software & \\
Telecommunications & 64.2 \\
Renting of office machinery and & 71.33 \\
equipment including computers & 72 \\
Computer and related activities & \\
\hline \hline
\end{tabular}

$\dagger$ Not included in the definition of the OECD (2000, p. 249).

Source: OECD (2000), own classification. 


\section{References}

Arnold, J. M. and Hussinger, K. (2004). Export Behavior and Firm Productivity in German Manufacturing: A Firm-Level-Analysis, Discussion Paper 04-12, ZEW Mannheim, Germany.

Bertschek, I. (2003). Infomation technology and productivity gains and cost savings in companies, in D. C. Jones (ed.), New Economy Handbook, Elsevier Science, Amsterdam, pp. 213-228.

Bertschek, I. and Kaiser, U. (2004). Productivity effects of organizational change: Microeconometric evidence, Management Science 50(3): 394-404.

Bresnahan, T. F., Brynjolfsson, E. and Hitt, L. M. (2002). Information technology, workplace organization and the demand for skilled labor: Firm-level evidence, Quarterly Journal of Economics 117(1): 339-376.

Brynjolfsson, E. and Hitt, L. M. (2000). Beyond computation: Information technology, organizational transformation and business performance, Journal of Economic Perspectives 14(4): 23-48.

Brynjolfsson, T. and Mendelson, H. (1993). Information systems and the organization of modern enterprises, Journal of Organizational Computing 3(3): 245-255.

Christensen, C. M. and Rosenbloom, R. S. (1995). Explaining the attackers advantage: technological paradigms, organizational dynamics, and the value network, Research Policy 24: 233-257.

Dewan, S. and Min, C.-K. (1997). The substitution of information technology for other factors of production: A firm-level analysis, Management Science 43(12): 1660-1675.

Garicano, L. and Kaplan, S. N. (2000). The effects of business-to-business ecommerce on transaction costs, NBER Working Paper 8017, National Bureau of Economic Research, Cambridge, MA.

Greene, W. H. (2000). Econometric Analysis, Prentice Hall, New Jersey. fourth edition.

Lucking-Reiley, D. and Spulber, D. F. (2001). Business-to-business electronic commerce, Journal of Economic Perspectives 15(1): 55-68.

Maddala, G. (1983). Limited Dependent and Qualitative Variables in Econometrics, Cambridge University Press.

Milgrom, P. and Roberts, J. (1990). The economics of modern manufacturing: Technology, strategy, and organization, American Economic Review 80(3): 511-528.

NFO Infratest (2003). Monitoring Informationswirtschaft, 6. Faktenbericht, Bundesministerium für Wirtschaft und Arbeit. 
OECD (1999). Economic growth in the OECD area: Are the disparities growing?, Report, OECD, Paris.

OECD (2000). Information Technology Outlook, OECD, Paris.

Prantl, S. (2001). Financial distress, liquidations and subsidization of young firms, Doctoral dissertation, University of Mannheim, Germany.

Radner, R. (1993). The organization of decentralized information processing, Econometrica 62: 1109-1146. 